\title{
Mitochondrial apoptotic cell death and moderate superoxide generation upon selective activation of non-desensitizing AMPA receptors in hippocampal cultures
}

\author{
A. Cristina Rego, Nuno M. Monteiro, Ana P. Silva, Joana Gil, João O. Malva \\ and Catarina R. Oliveira \\ Institute of Biochemistry, Faculty of Medicine and Center for Neuroscience and Cell Biology, University of Coimbra, Coimbra, \\ Portugal
}

\begin{abstract}
In the present work we investigated the effect of selective stimulation of non-desensitizing $\alpha$-amino-3-hydroxy-5-methyl4-isoxazolepropionate (AMPA) receptors in the intracellular processes leading to hippocampal neuronal death and production of reactive oxygen species (ROS). Activation of AMPA receptors in the presence of cyclothiazide (CYZ), a blocker of AMPA receptor desensitization, resulted in the death of approximately $25 \%$ of neurones, which was prevented by $2,3-$ dihydroxy-6-nitro-7-sulphamoyl-benzo(f)quinoxaline (NBQX), an AMPA-preferring receptor antagonist. (+)-5-Methyl-10,11dihydro-5H-dibenzo[a,d]cyclohepten-5,10-imine hydrogen maleate (MK-801) protected the neurones from necrotic death induced by AMPA or NMDA receptor activation. Neurodegeneration caused by selective activation of non-desensitizing AMPA receptors, in the presence of AMPA, CYZ and MK-801, significantly decreased the number of $\mathrm{Co}^{2+}$-positive neurones,
\end{abstract}

used as a cytochemical marker of $\mathrm{Ca}^{2+}$-permeable AMPA receptors, but maintained intracellular ATP/ADP. The AMPAmediated apoptotic cell death involved mitochondrial cytochrome $c$ release and the activation of caspases- 1 and -3 , which was prevented by NBQX. Interestingly, although selective activation of AMPA receptors was not associated with production of intracellular peroxides, a moderate increase in superoxide production was observed upon exposure to antimycin A (AA). Furthermore, increased activity of Mnsuperoxide dismutase (SOD) was observed on selective activation of non-desensitizing AMPA receptors. Taken together, these data make important contributions to the elucidation of the downstream pathways activated in AMPA receptor-mediated excitotoxicity in cultured rat hippocampal neurones.

Keywords: AMPA receptors, caspases, cytochrome $c$, hippocampal neurones, neurotoxicity, reactive oxygen species. J. Neurochem. (2003) 86, 792-804.
Activation of $\alpha$-amino-3-hydroxy-5-methyl-4-isoxazolepropionate (AMPA) receptors produces fast and rapidly desensitizing responses, which can be blocked by specific drugs, such as cyclothiazide (CYZ), a preferential blocker of the AMPA receptor subtype (Partin et al. 1993). This blockade is associated with a higher toxicity, because the receptors stay open for longer periods and may be permeable to $\mathrm{Ca}^{2+}$, as shown in hippocampal or cortical neurones (May and Robinson 1993; Cebers and Liljequist 1995; Ohno et al. 1998), although populations of hippocampal neurones have shown distinct sensitivities to AMPA, kainate or CYZ in terms of neuronal viability and intracellular $\mathrm{Ca}^{2+}$ changes (Ambrósio et al. 2000). AMPA receptors assemble from the combination of GluR1 to GluR4 subunits, but the presence of GluR2 subunits, whose expression is regulated in a cell-specific manner, greatly reduces $\mathrm{Ca}^{2+}$ permeability,
Received January 3, 2003; revised manuscript received March 13, 2003; accepted March 31, 2003.

Address correspondence and reprint requests to Ana Cristina Rego, $\mathrm{PhD}$, Institute of Biochemistry, Faculty of Medicine, and Center for Neuroscience and Cell Biology, University of Coimbra, 3004-504 Coimbra, Portugal. E-mail: acrego@cnc.cj.uc.pt

Abbreviations used: AA, antimycin A; Ac-DEVD-pNA, $N$-acetylAsp-Glu-Val-Asp- $p$-nitroanilide; Ac-IETD-pNA, $N$-acetyl-Ile-Glu-ThrAsp- $p$-nitroanilide; Ac-YVAD-pNA, $N$-acetyl-Tyr-Val-Ala-Asp- $p$-nitroanilide; AMPA, $\alpha$-amino-3-hydroxy-5-methyl-4-isoxazolepropionate; $\mathrm{CYZ}$, cyclothiazide; $\mathrm{DCFH}_{2}-\mathrm{DA}$, dichlorodihydrofluorescein diacetate; DHR-123, dihydrorhodamine-123; KCN, potassium cyanide; LDH, lactate dehydrogenase; MAP, microtubule-associated protein; MK-801, (+)-5-methyl-10,11-dihydro-5H-dibenzo[a,d]cyclohepten-5,10-imine hydrogen maleate; MTT, 3-(4,5-dimethylthiazol-2-yl)-2,5-diphenyltetrazolium bromide; NBQX, 2,3-dihydroxy-6-nitro-7-sulphamoyl-benzo(f)quinoxaline; PBS, phosphate-buffered saline; PI, propidium iodide; PMSF, phenylmethylsulfonyl fluoride; ROS, reactive oxygen species; SOD, superoxide dismutase. 
voltage-dependent block by polyamines and single-channel conductance (Pellegrini-Giampietro et al. 1997; Tanaka et al. 2000 for review). Under physiological conditions, excitatory neurones in the hippocampus express abundant GluR2 mRNA, and exhibit low $\mathrm{Ca}^{2+}$ permeability (Geiger et al. 1995). Therefore, a decreased expression of GluR2 subunits has been implicated in neuronal vulnerability, leading to cell death under ischaemic conditions (Gorter et al. 1997; Opitz et al. 2000; Tanaka et al. 2000).

Activation of AMPA receptors is associated with intracellular $\mathrm{Ca}^{2+}$ accumulation, mitochondrial depolarization (Rego et al.2001) and production of reactive oxygen species (ROS), namely the superoxide anion (e.g. Carriedo et al. 1998). Mitochondrial dysfunction and swelling have been associated with the release of cytochrome $c$ into the cytoplasm, namely through the opening of the permeability transition pore, implicating the mitochondria as an important site in the regulation of cell death. Within the cytosol, cytochrome $c$ interacts with Apaf-1 in the presence of dATP, activating caspase-9, which further activates caspase- 3 and may result in apoptosis mediated by AMPA receptors. The neurotoxic effects of AMPA/kainate receptor stimulation, documented through the involvement of neuronal $\mathrm{Na}^{+}$loading on cytosolic $\mathrm{Ca}^{2+}$ changes and neuronal swelling (Itoh et al. 1998; Kiedrowski 1998; Rego et al. 2001), have been associated with both necrotic and/or apoptotic types of cell death, as reported in cerebellar granule cells (Simonian et al. 1996; Cebers et al. 1997) or cortical neurones (Larm et al. 1997). Moreover, blockade of AMPA receptor desensitization with CYZ was shown to modulate the receptor-mediated apoptosis in cortical neuronal cultures, as determined by monitoring cell viability and morphology (John et al. 1999). However, less is known about the influence of selective activation of AMPA receptors under non-desensitizing conditions on apoptotic features of cell death, such as cytochrome $c$ release or caspase activation, and their correlation with intracellular generation of ROS in hippocampal neurones.

In the present work we therefore investigated cell death after stimulation of desensitizing or non-desensitizing AMPA receptors in hippocampal neuronal cultures. Particular attention was given to the analysis of selective activation of AMPA receptors under non-desensitizing conditions, in the presence of CYZ (a preferential blocker of AMPA receptor desensitization) and (+)-5-methyl-10,11-dihydro-5H-dibenzo[a,d]cyclohepten-5,10-imine hydrogen maleate (MK-801), the noncompetitive inhibitor of NMDA receptors. Under these conditions, we show that brief stimulation of AMPA receptors induces hippocampal neuronal death by necrosis and apoptosis, release of cytochrome $c$, activation of caspases and DNA condensation/fragmentation (Monteiro et al. 2001). Concomitantly, a moderate generation of mitochondrial superoxide was counterbalanced by an increased activity of Mn-superoxide dismutase (SOD), although this did not involve the formation of intracellular peroxides (Monteiro et al. 2001). Because the hippocampus is involved in neurodegeneration caused by epileptic seizures, ischaemia or Alzheimer's disease, the increased sensitivity of hippocampal neurones to excitotoxicity mediated by selective AMPA receptor stimulation may be relevant in defining the vulnerability of neurones in this elective cerebral area.

\section{Materials and methods}

\section{Materials}

Neurobasal medium, B27 supplement, gentamicin and trypsin were from Gibco-BRL, Life Technologies (Paisley, Scotland, UK). AMPA, 2,3-dihydroxy-6-nitro-7-sulphamoyl-benzo(f)quinoxaline (NBQX) and CYZ were obtained from Tocris Cookson (Bristol, UK). Mitotracker-green, syto-13, propidium iodide (PI), anti-fade kit, Alexa Fluor-594 anti-mouse IgG and Alexa Fluor-488 antirabbit IgG were purchased from Molecular Probes (Leiden, The Netherlands). Antibody against the native or denatured form of cytochrome $c$ was obtained from PharMingen (San Diego, CA, USA). Anti-active caspase- 3 was obtained from Promega (Madison, WI, USA). Colorimetric substrates for caspases-1 and -3 were purchased from Calbiochem (San Diego, CA, USA). MK-801 was a kind gift from Merck Sharp \& Dohme Research Laboratories (Merck \& Co. Inc., Whitehouse Station, NJ, USA). All other reagents, including anti-microtubule-associated protein (MAP)-2 and caspase- 8 substrate, were obtained from Sigma Chemical (St Louis, MO, USA).

\section{Culture and incubation of rat hippocampal neurones}

Hippocampal neurones were obtained from 18-19-day-old Wistar rat embryos, according to the National Ethical Requirements for Animal Research and the European Convention for the Protection of Vertebrate Animals used for Experimental and other Scientific Purposes. The cells were dissociated with trypsin $(1 \mathrm{mg} / \mathrm{mL})$ for $15 \mathrm{~min}$ at $37^{\circ} \mathrm{C}$ and deoxyribonuclease $\mathrm{I}(0.15 \mathrm{mg} / \mathrm{mL})$ in $\mathrm{Ca}^{2+}-$ and $\mathrm{Mg}^{2+}$-free Hank's balanced salt solution (137 mM NaCl, $5.36 \mathrm{~mm}$ $\mathrm{KCl}, 0.44 \mathrm{~mm} \mathrm{KH}_{2} \mathrm{PO}_{4}, 0.34 \mathrm{~mm} \mathrm{Na} \mathrm{HPO}_{4} .2 \mathrm{H}_{2} \mathrm{O}, 4.16 \mathrm{~mm} \mathrm{NaH}-$ $\mathrm{CO}_{3}, 5 \mathrm{~mm}$ glucose, $1 \mathrm{~mm}$ sodium pyruvate and $10 \mathrm{~mm}$ HEPES, $\mathrm{pH}$ 7.4). The cells $\left(1 \times 10^{5}\right.$ cells $/ \mathrm{cm}^{2}$; plated on poly-L-lysinepretreated 12-well dishes for lactate dehydrogenase (LDH) and 3-(4,5-dimethylthiazol-2-yl)-2,5-diphenyltetrazolium bromide (MTT) assays, or six-well dishes for measurement of enzyme activities) were cultured for $7-8$ days $\left(95 \%\right.$ air, $\left.5 \% \mathrm{CO}_{2}\right)$ in serumfree Neurobasal medium, supplemented with B27 supplement (2\%), glutamate $(25 \mu \mathrm{M})$, glutamine $(0.5 \mathrm{~mm})$ and gentamicin $(0.12 \mathrm{mg} / \mathrm{mL})$, according to Ambrósio et al. (2000). For immunocytochemistry, morphological studies and analysis of ROS formation, neurones were mounted on coverslips that had been pretreated with poly-L-lysine $\left(45 \times 10^{3}\right.$ cells $\left./ \mathrm{cm}^{2}\right)$. These primary hippocampal neuronal cultures were shown to contain approximately $95 \%$ neurones, as determined by immunocytochemistry with anti-MAP-2 antibody and anti-glial fibrillary acidic protein. As demonstrated previously (Silva et al. 2001) MAP-2 was shown to be localized throughout the neurones, particularly in the dendrites.

Hippocampal neurones were exposed to AMPA $(100 \mu \mathrm{M})$, in the absence or presence of CYZ $(30 \mu \mathrm{M})$ and MK-801 $(10 \mu \mathrm{M})$ for 15 min, in supplemented Neurobasal medium. The cells were then 
washed twice with saline buffer ( $132 \mathrm{~mm} \mathrm{NaCl}, 4 \mathrm{~mm} \mathrm{KCl}, 1.4 \mathrm{~mm}$ $\mathrm{MgCl}_{2}, 1 \mathrm{~mm} \mathrm{CaCl} 2,6 \mathrm{~mm}$ glucose and $10 \mathrm{~mm}$ HEPES-Na, $\mathrm{pH}$ 7.4) and incubated for $24 \mathrm{~h}$ in supplemented Neurobasal medium. Some neurones were also incubated with NBQX $(20 \mu \mathrm{M})$, an AMPApreferring receptor antagonist. Where indicated, the neurones were exposed to NMDA $(100 \mu \mathrm{M})$ and glycine $(10 \mu \mathrm{M})$, in the presence of NBQX $(20 \mu \mathrm{M})$, in $\mathrm{Mg}^{2+}$-free medium.

\section{Analysis of neuronal death}

The integrity of the plasma membrane of hippocampal neurones was monitored by the leakage of $\mathrm{LDH}$, by following the rate of conversion of NADH to $\mathrm{NAD}^{+}$at $340 \mathrm{~nm}$, according to Bergmeyer and Bernt (1974). LDH released into the extracellular medium was expressed as a percentage of total LDH activity in the cells. Cell viability at $37^{\circ} \mathrm{C}$ was also measured by following the reduction of MTT at $570 \mathrm{~nm}$ (Mosmann 1983).

Analysis of neuronal death by apoptosis or necrosis was assessed using the fluorescent probes syto-13, a membrane-permeable green fluorescent dye that binds DNA and RNA, and PI, a non-membranepermeable red fluorescent dye that binds to DNA. Viable cells show a green nucleus labelled homogenously with syto-13, whereas apoptotic cells show condensed and fragmented nuclei labelled with syto-13 (primary apoptosis) or with syto-13 plus PI (secondary apoptosis). Necrotic neurones are visualized by an intense red fluorescence upon labelling with PI. The neurones were loaded for 3 min with a solution of saline buffer containing $4 \mu \mathrm{M}$ syto- 13 and $4 \mu \mathrm{g} / \mathrm{mL}$ PI. Viable, apoptotic or necrotic cells were counted by using an inverted Nikon Diaphot-TMD fluorescence microscope (Nikon Corporation, Tokyo, Japan), with a triple filter Omega XF63 (Omega Optical Inc., Brattleboro, VT, USA).

\section{Identification of $\mathrm{Ca}^{2+}$-permeable AMPA receptors}

After incubation for $24 \mathrm{~h}$, the cells were washed twice in HEPES buffer containing $146 \mathrm{mM} \mathrm{NaCl}, 4.2 \mathrm{mM} \mathrm{KCl}, 0.5 \mathrm{mM} \mathrm{MgCl}_{2}$, $0.8 \mathrm{mM} \mathrm{CaCl}_{2}, 20 \mathrm{~mm}$ HEPES and $55.6 \mathrm{~mm}$ glucose, at $\mathrm{pH} 7.4$, and stimulated with AMPA plus CYZ and MK-801 in HEPES buffer containing $5 \mathrm{mM} \mathrm{CoCl}_{2}$. The cells were washed twice in HEPES buffer containing $2 \mathrm{mM}$ EDTA then cobalt was precipitated with $0.12 \% \mathrm{Na}_{2} \mathrm{~S}$ for $5 \mathrm{~min}$. The cells were fixed with $4 \%$ paraformaldehyde containing $4 \%$ sucrose in phosphate-buffered saline (PBS) for $30 \mathrm{~min}$, followed by $1 \mathrm{~h}$ incubation at $50^{\circ} \mathrm{C}$ with $1 \mathrm{mg} / \mathrm{mL}$ $\mathrm{AgNO}_{3}$ in developing buffer (292 mм sucrose, $15.5 \mathrm{~mm}$ hydroquinone, $42 \mathrm{~mm}$ citric acid). The neurones were also visualized with anti-MAP-2 (1:500), after cell permeabilization with Triton X-100 $(0.2 \%)$. The neurones were visualized in an inverted Nikon Diaphot fluorescence microscope, with a triple filter Omega FX-64, and counted from arbitrary fields in the culture.

\section{Measurement of adenine nucleotides}

ATP and ADP were analysed after cell extraction with $0.3 \mathrm{M}$ perchloric acid $\left(0-4^{\circ} \mathrm{C}\right)$. The cells were centrifuged at $15800 \mathrm{~g}$ for $5 \mathrm{~min}$, and the pellet was solubilized with $0.1 \mathrm{M} \mathrm{NaOH}$ for total protein analysis by the Biorad method (Bradford 1976). The supernatants were neutralized with $3.3 \mathrm{M} \mathrm{KOH}$ in $1.67 \mathrm{M}$ Tris and further centrifuged at $15800 \mathrm{~g}$ for $10 \mathrm{~min}$. The supernatants were then stored at $-80^{\circ} \mathrm{C}$. They were assayed for adenine nucleotides by reverse-phase HPLC, using a mobile phase of $10 \mathrm{~mm} \mathrm{NaH}_{2} \mathrm{PO}_{4}$, $\mathrm{pH} 6.0$, and $14 \%$ methanol, at a flow rate of $1.5 \mathrm{~mL} / \mathrm{min}$.

\section{Immunocytochemistry}

For analysis of cytochrome $c$, the cells were washed three times with saline buffer and incubated with mitotracker-green (500 nM), a mitochondrial marker that is insensitive to the mitochondrial potential (Krohn et al. 1999). After fixation in 4\% paraformaldehyde containing $4 \%$ sucrose in PBS for $10 \mathrm{~min}$, the cells were washed three times with PBS and incubated with $20 \mathrm{~mm}$ glycine. After cell permeabilization in the presence of saponin $(0.1 \%)$, the cells were incubated with a specific antibody against the native form of cytochrome $c(1: 100)$, for $30 \mathrm{~min}$. For analysis of caspase-3, the cells were also fixed with $4 \%$ paraformaldehyde, permeabilized with $0.2 \%$ Triton (in PBS) for $5 \mathrm{~min}$, washed three times in PBS, and further incubated with a blocking buffer containing 3\% BSA in PBS $/ 0.1 \%$ Tween for $2 \mathrm{~h}$. The cells were incubated with anti-active caspase-3 $(1: 250)$ and anti-MAP-2 $(1: 500)$, overnight at $4{ }^{\circ} \mathrm{C}$. Cytochrome $c$ and MAP-2 were visualized by using the secondary antibody Alexa Fluor-594 anti-mouse IgG (1:200), whereas active caspase- 3 was visualized by using the secondary antibody Alexa Fluor-488 anti-rabbit $\operatorname{IgG}(1: 200)$. The cells were visualized by confocal microscopy (MRC 600; Bio-Rad, Hercules, CA, USA).

\section{Western blot analysis of cytochrome $c$}

The cells were extracted in buffer containing $250 \mathrm{~mm}$ sucrose, $20 \mathrm{~mm}$ HEPES, $10 \mathrm{~mm} \mathrm{KCl}, 1.5 \mathrm{~mm} \mathrm{MgCl}_{2}, 1 \mathrm{~mm}$ EDTA, $1 \mathrm{~mm}$ EGTA, pH 7.4, supplemented with $1 \mathrm{~mm}$ dithiothreitol, $100 \mu \mathrm{M}$ phenylmethylsulphonyl fluoride (PMSF) and protease inhibitor cocktail (1:100; Sigma), and centrifuged at $500 \mathrm{~g}$ for $12 \mathrm{~min}$ at $4{ }^{\circ} \mathrm{C}$. The mitochondrial fraction was obtained by centrifugation at $12000 \mathrm{~g}$ for $20 \mathrm{~min}$. The proteins were separated by electrophoresis on $15 \%$ sodium dodecyl sulfate polyacrylamide gels and transferred to a polyvinylidene difluoride membrane. The membrane was further blocked with $5 \%$ fat-free milk before incubation with a specific antibody against the denatured form of cytochrome $c$ $(1: 1000)$. An anti-mouse IgG secondary antibody (1:25 000) was used (ECF system; Amersham, UK) and visualized by scanning on a STORM 860 (Molecular Dynamics, Sunnyvale, CA, USA), using a blue excited fluorescence.

\section{Caspase activity assay}

The cells were rinsed twice in PBS and then extracted with a lysis buffer (1 mM sodium EDTA, $1 \mathrm{~mm}$ sodium EGTA, $2 \mathrm{~mm} \mathrm{MgCl}_{2}$, $25 \mathrm{~mm}$ HEPES, pH 7.5) containing $2 \mathrm{~mm}$ dithiothreitol, $0.1 \mathrm{~mm}$ PMSF and protease cocktail inhibitors ( $1: 100$; Sigma). The samples were further centrifuged at $25800 \mathrm{~g}$ for $10 \mathrm{~min}$ at $4^{\circ} \mathrm{C}$. The resulting supernatants (equivalent to $25 \mu \mathrm{g}$ protein, as determined by the Biorad method) were used to determine the activity of caspases, at $405 \mathrm{~nm}$, in buffer containing $10 \%$ sucrose, $1 \% 3$ [(3-cholamidopropyl)dimethylammonio]-1-propanesulfonate (CHAPS), 25 mм HEPES, pH 7.4, $10 \mathrm{mM}$ dithiothreitol, and $100 \mu \mathrm{M}$ of the colorimetric substrates $N$-acetyl-Tyr-Val-Ala-Asp- $p$-nitroanilide (Ac-YVAD-pNA), $N$-acetyl-Asp-Glu-Val-Asp- $p$-nitroanilide (Ac-DEVD-pNA) or $N$-acetylIle-Glu-Thr-Asp- $p$-nitroanilide (Ac-IETD-pNA) for measurement of caspase-1, caspase-3 and caspase-8-like activities respectively.

\section{Measurement of ROS generation}

Intracellular peroxides were measured by following the oxidation of dichlorodihydrofluorescein diacetate $\left(\mathrm{DCFH}_{2}-\mathrm{DA} ; 20 \mu \mathrm{M}\right)$ or dihydrorhodamine-123 (DHR-123; $5 \mu \mathrm{M}$ ) to the fluorescent DCF or 
rhodamine-123 respectively, according to Royall and Ischiropoulos (1993) and Rego et al. (1999). The neurones were loaded with $\mathrm{DCFH}_{2}$-DA for $20 \mathrm{~min}$ in saline buffer at $37^{\circ} \mathrm{C}$, in the dark. The increase in DCF fluorescence was measured in saline buffer $\left(37^{\circ} \mathrm{C}\right)$, with excitation at $502 \mathrm{~nm}$ and emission at $550 \mathrm{~nm}$. The increase in fluorescence of DHR-123 was measured in saline buffer $\left(37^{\circ} \mathrm{C}\right)$, with excitation at $500 \mathrm{~nm}$ and emission at $536 \mathrm{~nm}$. Loading of the probes was renewed for each experiment.

Superoxide generation was determined after incubation with $5 \mu \mathrm{M}$ hydroethidine for $60 \mathrm{~min}$ at $37^{\circ} \mathrm{C}$ (the probe was also renewed for each experiment), according to the method described in single cells by Bindokas et al. (1996) or Budd et al. (1997). The fluorescence of ethidium, obtained after oxidation of hydroethidine (dihydroethidium) by superoxide was measured in the cuvette for $20 \mathrm{~min}$ at $37^{\circ} \mathrm{C}$, with excitation at $548 \mathrm{~nm}$ and emission at $620 \mathrm{~nm}$. A SPEX Fluorolog spectrometer (Industries Inc., Edison, NJ, USA) equipped with a temperature-controlled water bath was used in these experiments.

\section{Measurement of specific SOD activity}

To determine the activity of SOD (total and Mn-SOD), the hippocampal neurones were extracted with $0.5 \%$ NP-40, according to the method described by Troy and Shelanski (1994) and Troy et al. (2000). Briefly, the NP-40 cellular extracts were incubated in buffer containing $50 \mathrm{~mm} \mathrm{NaHCO}_{3}, 0.1 \mathrm{~mm}$ EDTA, pH 10.2, plus $0.03 \%$ Triton X-100, $100 \mu \mathrm{M}$ xanthine and $0.025 \mathrm{U} / \mathrm{mL}$ xanthine oxidase. The reduction of nitroblue tetrazolium $(25 \mu \mathrm{M})$ was measured at $560 \mathrm{~nm}$ in the absence or presence of $1 \mathrm{~mm}$ potassium cyanide $(\mathrm{KCN})$, to discriminate $\mathrm{Cu} / \mathrm{Zn}-\mathrm{SOD}$ from $\mathrm{Mn}-\mathrm{SOD}$. Total SOD activity was measured in the absence of $\mathrm{KCN}$, whereas MnSOD activity was measured in the presence of $\mathrm{KCN}$, which inhibits $\mathrm{Cu} / \mathrm{Zn}-\mathrm{SOD}$.

\section{Data analysis}

Data are the mean \pm SEM from at least three experiments, performed in duplicate or triplicate, as indicated in figure legends. Statistical analysis was performed by unpaired student's $t$-test or by one-way ANOvA, followed by Tukey post-hoc test; $p<0.05$ was considered significant.

\section{Results}

\section{Selective activation of AMPA receptors mediates} hippocampal neuronal death by apoptosis and necrosis Changes in neuronal viability associated with the stimulation of AMPA receptors under desensitizing or non-desensitizing conditions were analysed by the MTT assay (Fig. 1a) and the release of LDH (Fig. 1b), which demonstrate the cellreducing capacity and the disruption of the plasma membrane respectively. Activation of AMPA receptors under nondesensitizing conditions in the presence of AMPA $(100 \mu \mathrm{M})$ plus CYZ $(30 \mu \mathrm{M})$, a preferential blocker of AMPA receptor desensitization, was associated with a significant decrease in cell viability (by about 25\%). In previous studies, $30 \mu \mathrm{M}$ CYZ was shown to maximally decrease the ability of hippocampal neurones to reduce MTT (A. F. Ambrósio,
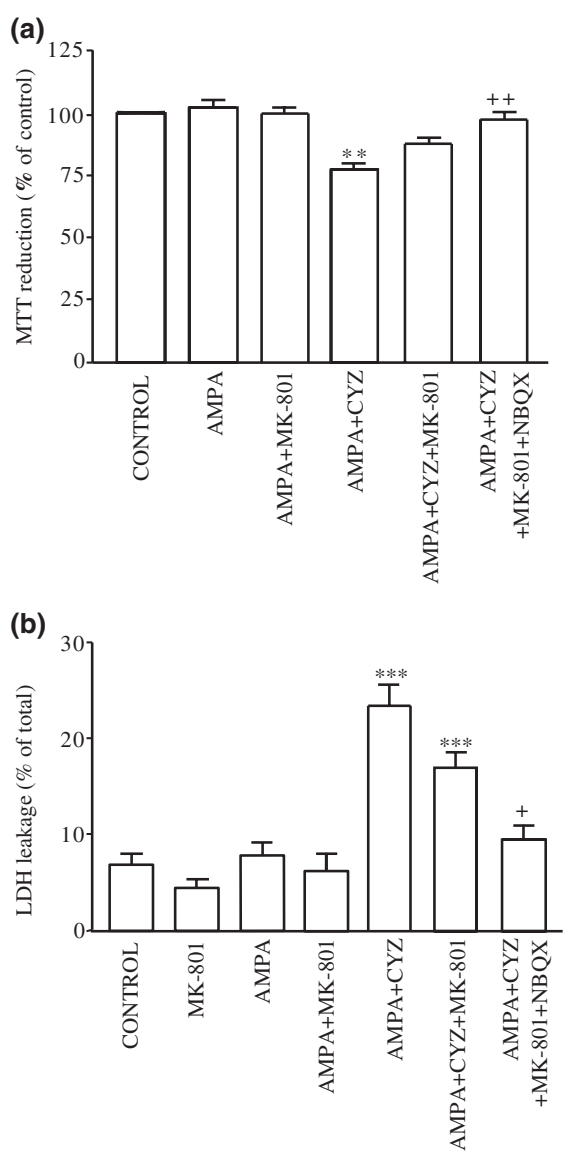

Fig. 1 MTT reduction or LDH leakage upon selective activation of non-desensitizing AMPA receptors. Hippocampal neurones were exposed to $100 \mu \mathrm{m}$ AMPA with or without $30 \mu \mathrm{M} \mathrm{CYZ}$ and $10 \mu \mathrm{M}$ MK801 , and further evaluated for changes in cell viability by the MTT test (a) or by the release of LDH (b). NBQX (20 $\mu \mathrm{m})$ prevented the decrease in MTT reduction (a) or LDH leakage (b) induced by AM$\mathrm{PA}+\mathrm{CYZ}$ in the presence of MK-801. Values are mean \pm SEM of three to 14 experiments in triplicate. ${ }^{\star *} p<0.01,{ }^{* \star *} p<0.001$ versus control; $+p<0.05$ and $++p<0.01$ versus AMPA + CYZ + MK-801treated cells (one-way ANOVA followed by Tukey post-hoc test).

unpublished results). Incubation with MK-801 (Figs 1a and b), to counteract the effect of secondary NMDA receptor activation (Itoh et al. 1998), partially prevented the neuronal death observed following treatment with AMPA plus CYZ. Substantial prevention of cell death induced by AMPA in the presence of CYZ was observed after incubation with MK801 and NBQX, antagonists of NMDA and AMPA receptors respectively (Figs 1a and b). Nevertheless, the alterations in cell viability between the distinct experimental conditions could not be attributed to significant changes in intracellular ATP/ADP levels (Table 1).

Features of apoptotic, necrotic or viable cells were examined by counting the number of hippocampal neurones labelled with the fluorescent probes syto-13 (membrane permeable) and PI (membrane impermeable), a method used 
Table 1 Intracellular levels of ATP/ADP in hippocampal neurones incubated with AMPA, under desensitizing or non-desensitizing conditions

\begin{tabular}{ll}
\hline & ATP/ADP \\
\hline Control & $12.89 \pm 0.86$ \\
MK-801 & $15.44 \pm 2.07$ \\
AMPA & $15.76 \pm 1.30$ \\
AMPA + MK-801 & $15.09 \pm 0.98$ \\
AMPA + CYZ & $16.17 \pm 2.68$ \\
AMPA + CYZ + MK-801 & $13.54 \pm 1.09$ \\
AMPA + CYZ + MK-801 + NBQX & $13.28 \pm 0.49$ \\
\hline
\end{tabular}

Data are the mean \pm SEM of three to six experiments, run in triplicate. Hippocampal neurones were incubated with $100 \mu \mathrm{M}$ AMPA, in the absence or in the presence of CYZ (30 $\mu \mathrm{M}), \mathrm{MK}-801$ (10 $\mu \mathrm{m})$ or NBQX $(20 \mu \mathrm{M})$ for $15 \mathrm{~min}$, and further incubated in Neurobasal medium for $24 \mathrm{~h}$, in the absence of the drugs. The levels of ATP/ADP were determined by reverse-phase HPLC after perchloric extraction. No statistical differences were observed.

to analyse chromatin condensation and/or fragmentation (Figs 2 and 3). Compared with cells incubated under control conditions, which showed some apoptotic features (about $10 \%$ of total cells), activation of AMPA receptors under desensitizing conditions (AMPA alone) induced a significant increase in the percentage of cells (approximately 10\%) undergoing necrosis, which was completely prevented by MK-801 (Fig. 2). This small percentage of cells undergoing necrosis upon incubation with AMPA (Fig. 2) was not observed when measuring the changes in hippocampal neuronal viability (Figs $1 \mathrm{a}$ and $\mathrm{b}$ ). Selective activation of AMPA receptors under non-desensitizing conditions induced by $\mathrm{CYZ}$, and in the presence of MK-801, was associated with both apoptotic and necrotic cell death. Furthermore, in the presence of AMPA plus CYZ, MK-801 was shown to significantly decrease the number of necrotic neurones (by about 5\% compared with AMPA/CYZ alone; $p<0.05$ ), despite maintenance of the number of viable neurones and a non-significant increase (about 5\%) in the number of apoptotic neurones (Fig. 2). A decrease in the number of neurones entering necrosis upon exposure to MK-801, compared with AMPA/CYZ only (Fig. 2), was reflected by a decrement in LDH release under the same experimental conditions (Fig. 1b), suggesting the prevention of plasma membrane disruption and, consequently, a decrease in the number of neurones undergoing necrosis. In addition, hippocampal neuronal death was completely prevented upon blockade of both NMDA and AMPA receptors, respectively, in the presence of MK-801 and NBQX (Fig. 2), similar to data in Fig. 1. Incubation with MK-801 (Figs 1b and 2) or CYZ (not shown) alone did not significantly affect the percentage of viable, apoptotic or necrotic neurones, compared with the control.

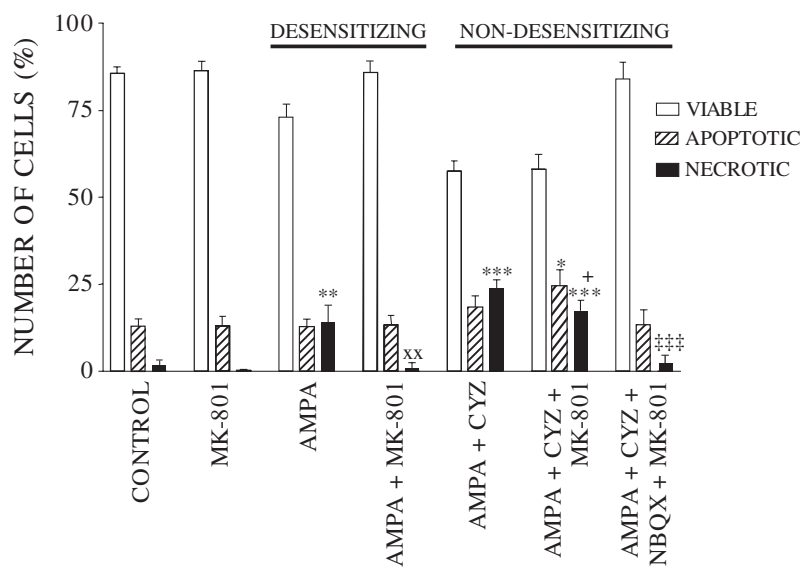

Fig. 2 Cell death by necrosis or apoptosis induced by activation of AMPA receptors, under desensitizing or non-desensitizing conditions. Hippocampal neurones were incubated with $100 \mu \mathrm{M}$ AMPA, in the absence (desensitizing) or in the presence of $30 \mu \mathrm{M} \mathrm{CYZ} \mathrm{(non-}$ desensitizing). MK-801 (10 $\mu \mathrm{M})$, a non-competitive antagonist of NMDA receptors, was further tested. Necrotic and apoptotic neuronal death, determined with syto- 13 and $\mathrm{PI}$, was prevented upon addition of $20 \mu \mathrm{M}$ NBQX, an AMPA-preferring receptor antagonist, in neurones exposed to AMPA $+C Y Z+M K-801$. Values are mean \pm SEM of five to 13 experiments. A total of about 200 cells per coverslip was counted, from three coverslips per experiment. ${ }^{*} p<0.05$, ${ }^{* *} p<0.01$, ${ }^{* * *} p<0.001$ versus respective control; $+p<0.05$ versus AMPA + CYZ-treated cells; $+\$ p<0.001$ versus AMPA + CYZ + MK-801treated cells; $x x p<0.01$ versus AMPA-treated cells (one-way ANOVA followed by Tukey post-hoc test).

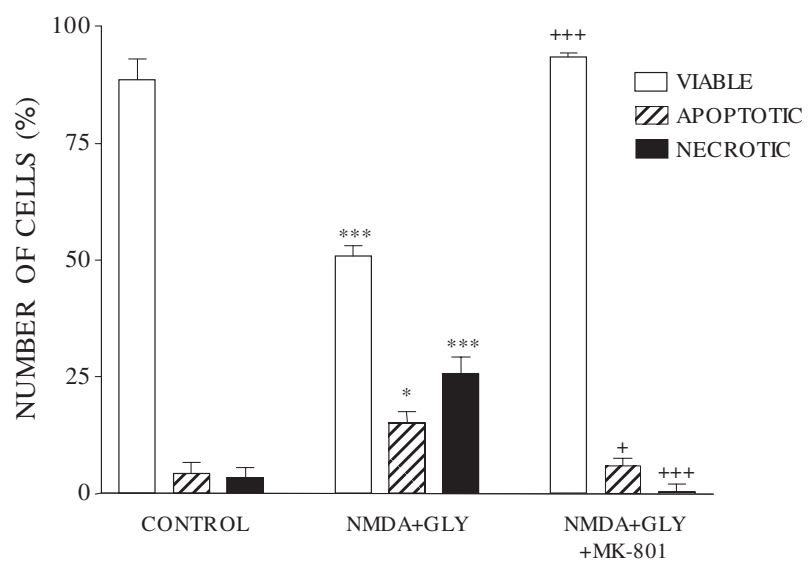

Fig. 3 Selective NMDA-induced hippocampal neuronal death. The neurones were incubated with $100 \mu \mathrm{M}$ NMDA plus $10 \mu \mathrm{m}$ glycine (GLY), in the presence of NBQX (20 $\mu \mathrm{M})$ in $\mathrm{Mg}^{2+}$-free medium. Neuronal death, determined with syto-13 and PI, was almost completely abolished upon addition of $10 \mu \mathrm{M}$ MK-801, an NMDA receptor antagonist. Values are mean \pm SEM of three to four experiments. A total of about 200 cells per coverslip was counted, from three coverslips per experiment. ${ }^{*} p<0.05,{ }^{* * *} p<0.001$ versus control; $+p<0.05,+++p<0.001$ versus NMDA + GLY-treated cells (one-way ANOVA followed by Tukey post-hoc test). 
In order to evaluate the role of NMDA receptor activation in hippocampal neuronal death, we examined the effect of NMDA receptor stimulation upon exposure to NMDA plus glycine in $\mathrm{Mg}^{2+}$-free medium. The medium also contained NBQX to eliminate the effect of AMPA receptors (Fig. 3). Under these conditions, the number of viable cells was greatly decreased, concomitant with an increase in the percentage of apoptotic (about 15\%) and, in particular, necrotic (about 25\%) cells. Furthermore, specific blockade of NMDA receptors with MK-801 reduced the numbers of both apoptotic and necrotic cells and enhanced the percentage of viable cells, similar to control conditions (Fig. 3). These results show that apoptosis and necrosis are common features induced by selective activation of both AMPA and NMDA receptors. Furthermore, subsequent NMDA receptor activation enhanced the number of necrotic neurones upon stimulation of AMPA receptors.
To determine whether hippocampal neuronal death was associated with neurones containing $\mathrm{Ca}^{2+}$-permeable AMPA receptors, the neurones (control or AMPA/CYZ treated) were subjected to secondary activation of AMPA receptors under non-desensitizing conditions, in the presence of MK-801 and $\mathrm{Co}^{2+}$, a procedure known to enhance intracellular $\mathrm{Co}^{2+}$ labelling associated with the presence of $\mathrm{Ca}^{2+}$-permeable AMPA receptors (Malva et al. 2003). Figure 4(a-d) shows that, in the population of hippocampal neurones visualized with the neuronal marker MAP-2, only some control neurones were stained with $\mathrm{Co}^{2+}$, indicating that a small percentage of cells contained $\mathrm{Ca}^{2+}$-permeable AMPA receptors (about 15 $20 \%)$. Furthermore, we observed a significant decrease $(\sim 25 \%$ of control) in $\mathrm{Co}^{2+}$-stained neurones after non-desensitizing activation of AMPA receptors (Fig. 4c-e), suggesting that the neurones containing $\mathrm{Ca}^{2+}$-permeable AMPA receptors were partially sensitive to the excitotoxic insult.
Fig. $4 \mathrm{Co}^{2+}$ staining after selective activation of AMPA receptors in the presence of CYZ. Hippocampal neurones were incubated with $100 \mu \mathrm{M}$ AMPA in the presence of $30 \mu \mathrm{M} \mathrm{CYZ} \mathrm{(non-desensitizing} \mathrm{conditions)}$ and $10 \mu \mathrm{M}$ MK-801 (c,d), and compared with control neurones incubated with MK801 only $(a, b)$. After $24 \mathrm{~h}$ incubation in Neurobasal medium, the neurones (control and AMPA/CYZ-treated) were stimulated with AMPA + CYZ + MK-801, in the presence of $\mathrm{Co}^{2+} . \mathrm{Co}^{2+}$-stained neurones were counted from an arbitrary field in the culture, and compared with anti-MAP-2 staining (red). The arrows, in $\mathrm{Co}^{2+}$-stained neurones, but not those stained for MAP-2 (b,d), show hippocampal neurones containing $\mathrm{Ca}^{2+}$-permeable AMPA receptors. Note that (a) or (b) (control) and (c) or (d) (AMPA/CYZ) are representative images from four independent experiments. (e) Changes in $\mathrm{Co}^{2+}$ staining over the total MAP-2 staining of AMPA + CYZ + MK-801treated hippocampal neurones compared with the control (in the presence of MK801). Values are mean \pm SEM from four experiments run in triplicate. A total of about 200 cells per coverslip were counted, from three coverslips per experiment. ${ }^{*} p<0.05$ versus control (unpaired student's $t$-test).

CONTROL + MK-801
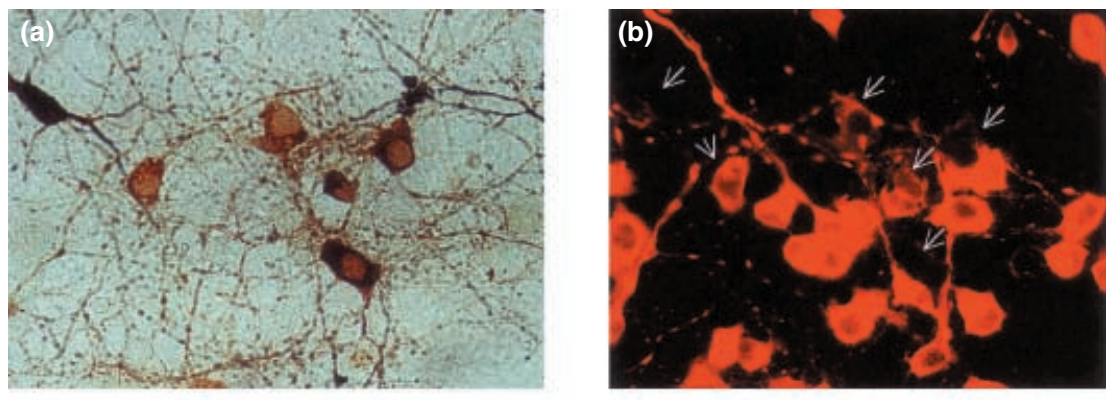

$\mathrm{AMPA}+\mathrm{CYZ}+\mathrm{MK}-801$

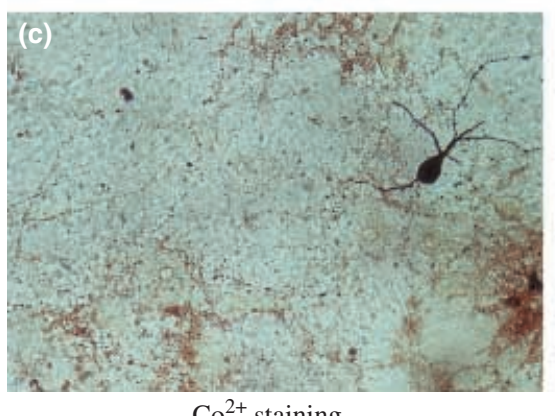

$\mathrm{Co}^{2+}$ staining

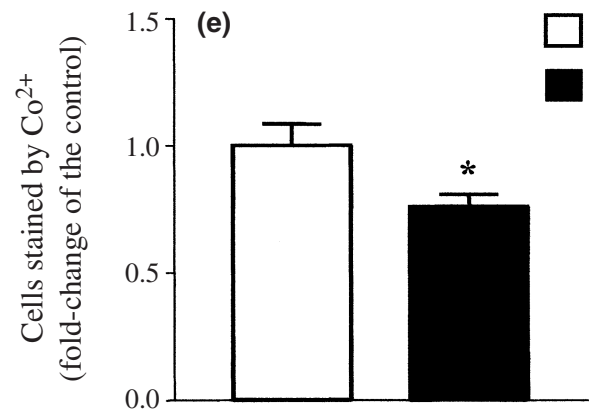

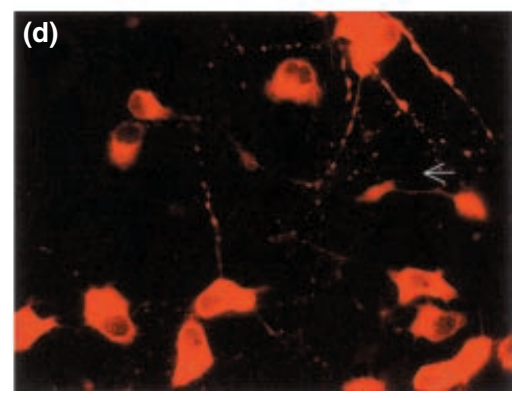

anti-MAP2

CONTROL+MK-801

$\mathrm{AMPA}+\mathrm{CYZ}+\mathrm{MK}-801$ 
Selective stimulation of AMPA receptors under non-desensitizing conditions induces mitochondrial cytochrome $c$ release and activation of caspases

In order to examine whether the features of cell death induced by selective activation of AMPA receptors under non-desensitizing conditions (in the presence of CYZ and MK-801) involved mitochondria-induced release of apoptotic factors, we analysed the release of mitochondrial cytochrome $c$ and the activation of caspases.

Figure 5 shows a decrease in the number of cytochrome $c$-like immunoreactive neurones on incubation with AMPA plus CYZ (Fig. 5b), compared with the control (Fig. 5a), as determined by a decrease in the co-localization of cytochrome $c$ with the mitochondria. These results were confirmed by western blotting, using an antibody against the denatured form of cytochrome $c$, and evaluated as a percentage of cytochrome $c$ retained within the organelle (Fig. 5d). These results were shown to be receptor dependent, because NBQX $(20 \mu \mathrm{M})$ prevented the decrease in mitochondrial retention of cytochrome $c$ observed on exposure to AMPA, CYZ and MK-801 (Figs 5c and d).

Because activation of caspases occurs subsequently to mitochondrial cytochrome $c$ release, we also determined the activation of caspases- $1,-3$ and -8 by immunocytochemistry or with colorimetric substrates (Fig. 6). Interestingly, in hippocampal neurones exposed to AMPA plus CYZ and MK-801 a predominant localization of active caspase-3 was observed in the nucleus (Figs $6 \mathrm{~d}-\mathrm{f}$ ), as determined by using an antibody against its active form. Incubation with NBQX (Figs $6 \mathrm{~g}-\mathrm{i}$ ) prevented the activation of caspase- 3 induced by AMPA plus CYZ. Caspase-3 activity was confirmed by following the increase in the cleavage of Ac-DEVD-pNA (Fig. 6j). Under these conditions, caspase-8 activity was not significantly changed (Fig. 6k). Interestingly, a significant increase in Ac-YVAD-pNA cleavage, a substrate that is able to interact with caspase-1, was observed in extracts from neurones incubated with AMPA plus CYZ and MK-801 (Fig. 61).

\section{Selective activation of AMPA receptors predisposes hippocampal neurones to enhanced Mn-SOD activity} Because oxidative stress has been implicated in cell death by necrosis and apoptosis (Rego et al. 1999; Luetjens et al. 2000; Sugawara et al. 2002), we used distinct fluorescent probes to analyse the production of intracellular ROS induced by selective activation of non-desensitizing AMPA receptors, in the presence of AMPA plus CYZ and MK-801.

In order to explore the production of mitochondrial superoxide, the oxidation of hydroethidine, which generates the fluorescent ethidium, was followed in a population of control or AMPA-stimulated hippocampal neurones. Under basal conditions, no significant changes in superoxide anion formation were observed (Fig. 7). However, incubation with $5 \mu \mathrm{M}$ antimycin A (AA), a specific inhibitor of mitochondrial complex III, significantly enhanced ethidium fluorescence in hippocampal neurones stimulated with AMPA plus CYZ in the presence of MK-801, compared with controls (Fig. 7). A low response to AA in the population of control hippocampal neurones may be explained by the great variability of AAinduced changes in ethidium fluorescence, as observed in single-cell analysis (data not shown). The data suggest that selective activation of AMPA receptors under non-desensitizing conditions predisposes the hippocampal neurones to increased formation of mitochondrial superoxide. Under the same experimental conditions, an increase in the activity of the mitochondrial antioxidant enzyme Mn-SOD was also observed (Fig. 8), suggesting a protective effect against an increase in superoxide production. No significant changes in the protein expression levels of Mn-SOD were observed in western blot analysis (not shown). In addition, NBQX prevented the increase in Mn-SOD activity observed upon incubation with AMPA, CYZ and MK-801 (Fig. 8), providing evidence for a receptor-specific effect.

Because increased SOD activity is associated with an increase in hydrogen peroxide, we also examined the formation of intracellular peroxides, by following the oxidation of $\mathrm{DCFH}_{2}$-DA and DHR-123 (Table 2). These probes have been reported to be oxidized by ROS, with the exception of superoxide (Royall and Ischiropoulos 1993). Table 2 shows that the formation of peroxides was not significantly different in control or AMPA/CYZ-stimulated neurones, under basal or hydrogen peroxide-stimulated conditions.

\section{Discussion}

In this work we showed that selective activation of AMPA receptors under non-desensitizing conditions induces hippocampal neuronal death by necrosis and apoptosis. Cell death by apoptosis was evaluated by the release of cytochrome $c$, the activation of caspases- 1 and -3 , and chromatin condensation/fragmentation, which was prevented by specific blockade of AMPA receptors. The increase in hippocampal neuronal sensitivity predisposed to a moderate generation of mitochondrial superoxide and an AMPA receptor-mediated increase in the activity of Mn-SOD, which may counterbalance the neurotoxic effects induced by the radical. However, excitotoxicity induced by AMPA could not be accounted for by a significant increase in intracellular peroxide formation, excluding the occurrence of severe oxidative stress.

In agreement with previous published evidence of cell death by apoptosis upon exposure to kainate (Campagne et al. 1995; Simonian et al. 1996), selective AMPA receptor activation (Cebers et al. 1997; Larm et al. 1997) or activation of AMPA receptors under non-desensitizing conditions (John et al. 1999), we also observed that selective AMPA receptor stimulation induces cell death by necrosis and apoptosis (Figs 1 and 2), although the intracellular ATP/ADP 
Fig. 5 Effect of selective non-desensitizing AMPA receptor activation on the release of mitochondrial cytochrome c. Immunocytochemistry of control (a) or $100 \mu \mathrm{M}$ AM$\mathrm{PA}+30 \mu \mathrm{M} \quad \mathrm{CYZ}$-treated (b) hippocampal neurones, incubated in the presence of $10 \mu \mathrm{m}$ MK-801, show that cytochrome $c$ (cyt $c$ ) (red) is released from the mitochondria, identified with mitotracker-green (mt-green), following the activation of AMPA receptors under nondesensitizing conditions. Addition of NBQX $(20 \mu \mathrm{m})$ restored the co-localization of cytochrome $c$ and mitotracker-green (c). Images are representative of three independent experiments. (d) The graph represents the relative amount of cytochrome $c$ retained in the mitocondria (percentage of control), from four independent experiments, as determined by western blotting of mitochondria isolated from hippocampal neurones. Values are mean \pm SEM. The blot image shows a representative experiment carried out under the conditions depicted in the graph.

levels seemed to be preserved (Table 1). Importantly, secondary activation of NMDA receptors, which are stimulated by depolarization-induced removal of $\mathrm{Mg}^{2+}$ blockade, occurring after AMPA-mediated cytosolic $\mathrm{Na}^{+}$loading (Itoh et al. 1998), or selective activation of NMDA receptors, committed a higher percentage of neurones to necrosis, as observed in Figs 2 and 3. This observation should take into account that the hippocampal neurones used contain mostly NR1/ NR2B receptors and that increased expression of NR2A, followed by the expression of NR3 (postnatal), mainly associated with a lower $\mathrm{Ca}^{2+}$ permeability, occurs later in

mt-green
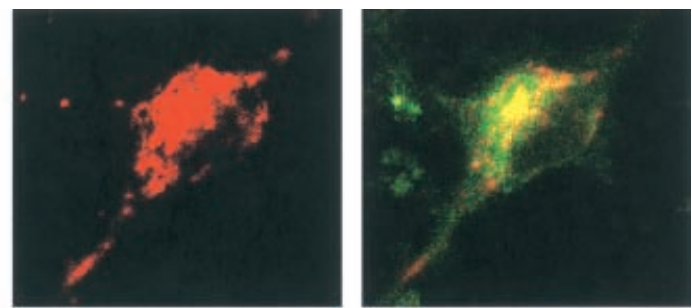

(b)

(c)
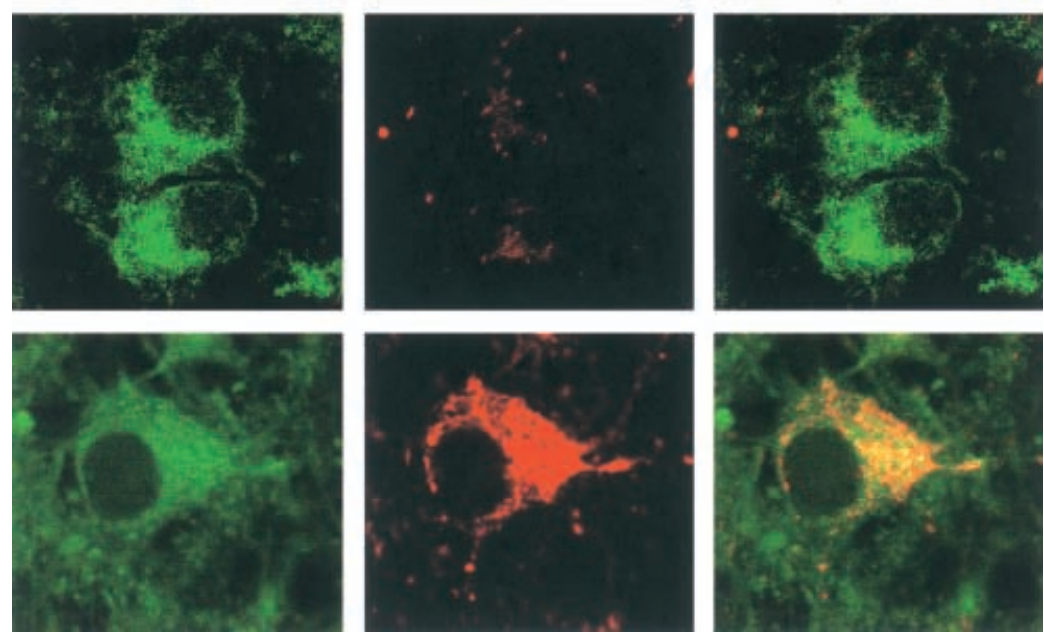

anti-cyt c

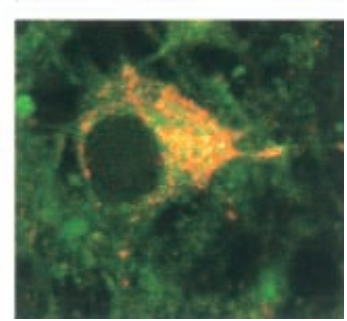

merge

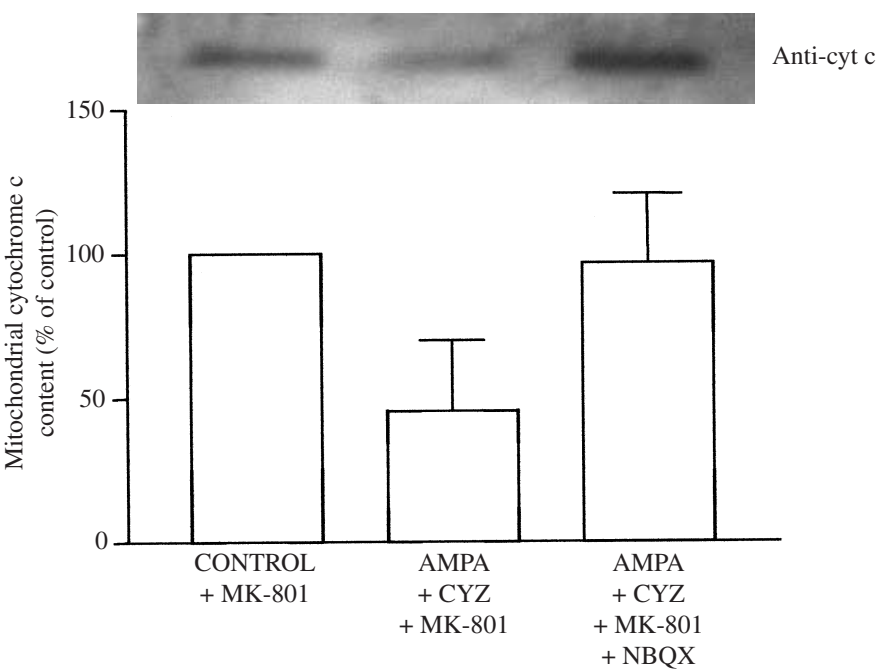

development (Barria and Malinow 2002; Matsuda et al. 2002).

According to data shown in Fig. 4, the significant decrease in the number of $\mathrm{Co}^{2+}$-positive neurones after selective activation of AMPA receptors suggests some susceptibility of hippocampal neurones containing $\mathrm{Ca}^{2+}$-permeable AMPA receptors (Malva et al. 2003). These receptors are controlled by the absence of GluR2 subunits (for review, Bennett et al. 1996; Pellegrini-Giampietro et al. 1997; Brorson et al. 1999). In previous studies, stimulation with kainate caused a rapid influx of $\mathrm{Ca}^{2+}$ into $\mathrm{Co}^{2+}$-positive cortical neurones, when 

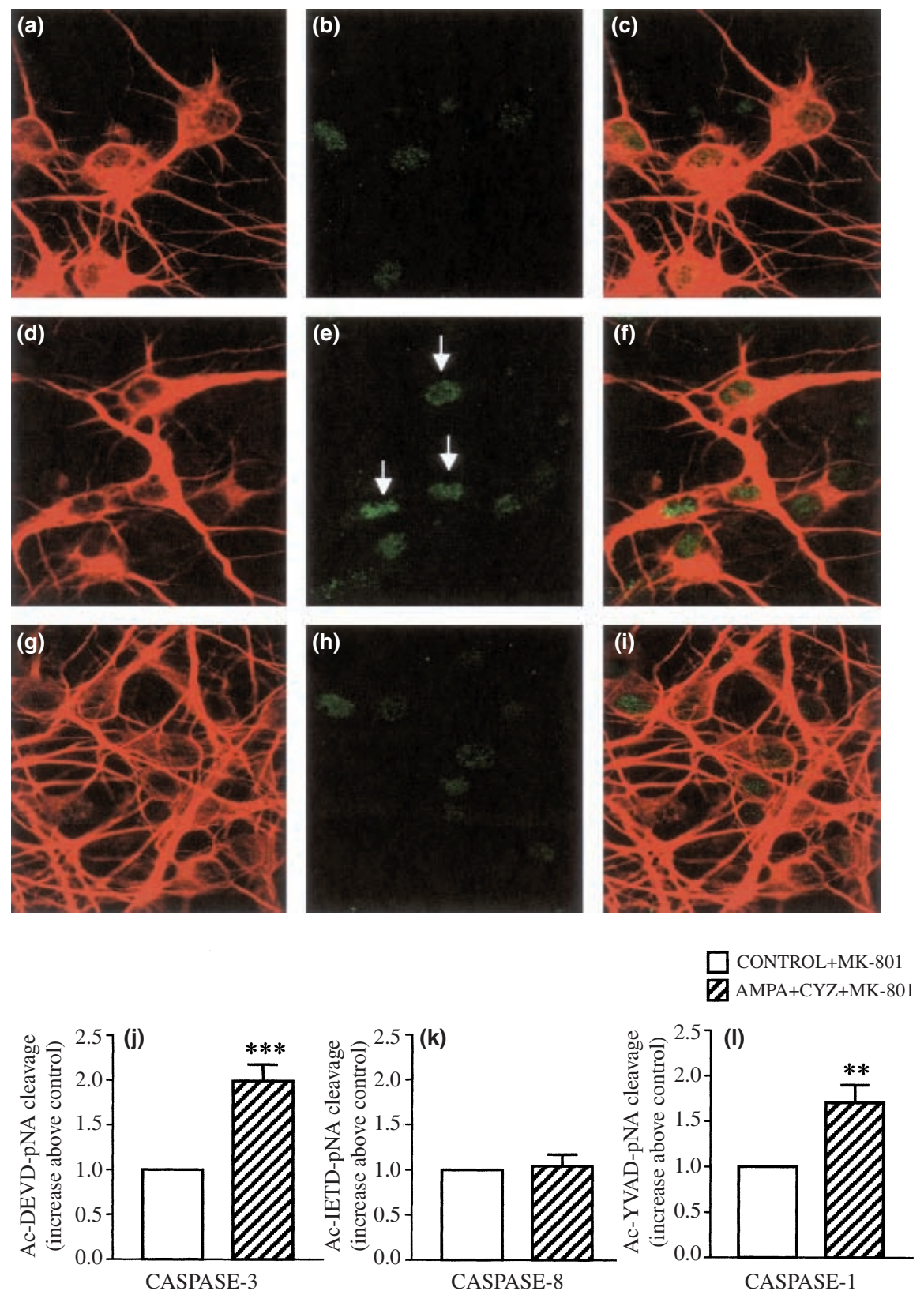

Fig. 6 Analysis of caspase activation upon exposure to AMPA under non-desensitizing conditions. (a-i) Caspase-3 activation was determined by immunocytochemistry (a,d,g: anti-MAP-2 in red; b,e,h: antiactive caspase-3 in green; $c, f, i$ : merged images) in control hippocampal cells $(\mathrm{a}-\mathrm{c})$ and upon exposure to $100 \mu \mathrm{M}$ AMPA $+30 \mu \mathrm{M} \mathrm{CYZ}+10 \mu \mathrm{m}$ MK-801 in the absence ( $d-f)$ or in the presence $(g-i)$ of $20 \mu \mathrm{M}$ NBQX. Active caspase- 3 is visualized more in the nucleus of treated cells, but

compared with NMDA stimulation, which was shown to be critical for determining neuronal injury ( $\mathrm{Lu}$ et al. 1996). Interestingly, the composition of AMPA receptors was changed upon global ischaemia in the hippocampus, namely through a reduction in GluR2 (but not GluR1) subunits in CA1 neurones, a hippocampal area selectively affected by isch- this is prevented by NBQX. (j-l) Activation of caspases upon selective activation of non-desensitizing AMPA receptors, in the presence of CYZ and MK-801. The activation of caspases-3, -8 or -1 was determined in the presence of the colorimetric substrates Ac-DEVD-pNA, Ac-IETD-pNA and Ac-YVAD-pNA respectively. Values are mean \pm SEM of three to four experiments. ${ }^{* *} p<0.01,{ }^{\star \star *} p<0.001$ versus control (unpaired student's $t$-test).

aemia, although not in CA3 pyramidal cells or in granule cells of the dentate gyrus (Opitz et al. 2000). Moreover, the expression of GluR2-lacking $\mathrm{Ca}^{2+}$-permeable AMPA receptors was closely related to an increase in $\mathrm{Ca}^{2+}$ influx mediated by activation of AMPA receptors in CA1 neurones exhibiting action potentials (Gorter et al. 1997), which are committed to 


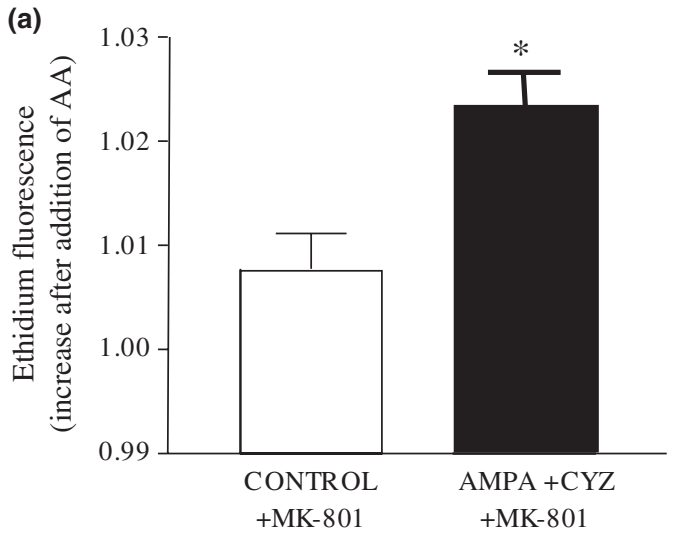

(b)

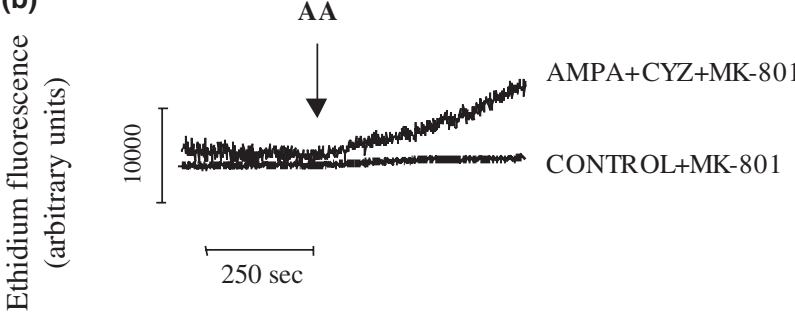

Fig. 7 Superoxide generation upon incubation with AMPA in the presence of CYZ and MK-801 in a population of hippocampal neurones. (a) Superoxide generation was determined with hydroethidine $(5 \mu \mathrm{M})$ in control and $100 \mu \mathrm{M}$ AMPA + $30 \mu \mathrm{M} \mathrm{CYZ} \mathrm{+} 10 \mu \mathrm{M}$ MK-801treated hippocampal neurones, after exposure to AA ( $5 \mu \mathrm{M})$, as shown in fluorescence traces of representative experiments (b). Values are mean \pm SEM of three experiments. ${ }^{*} p<0.05$ versus control (unpaired student's $t$-test).

die after ischaemia. It should be noted that, although the hippocampal cultures used in this study contain about $15-20 \%$ $\mathrm{Ca}^{2+}$-permeable AMPA receptors (in the absence of the Glu2 subunit), these cultures have been reported to show an increase in the expression of GluR2-containing AMPA receptors during development, after about 7-14 days in culture, related to a lower $\mathrm{Ca}^{2+}$ permeability (Pickard et al. 2000).

Apart from inducing fast necrotic neuronal death, the increase in intracellular $\mathrm{Ca}^{2+}$ concentration induced by stimulation with kainate, shown to interfere with the mitochondrial membrane potential (Rego et al. 2001), may well induce apoptotic neuronal death through the release of cytochrome $c$ and activation of the caspase cascade, as shown in this work. Thus, apoptosis probably occurs through AMPA receptor-dependent release of mitochondrial cytochrome $c$ (Fig. 5), a first potential trigger for activation of the caspase cascade, as observed by the activation of the executioner caspase-3 (Fig. 6). The observation of active caspase-3 localized in the nucleus may be accounted for by caspase-3-dependent regulation of caspase-activated Dnase/ DNA fragmentation factor 40 activity, a nuclease known to degrade chromosomal DNA into nucleosomal fragments in the nucleus (Lechardeur et al. 2000). Furthermore, because activation of caspase-3 may also result from the activation of caspase-1 or caspase-8, the results point to caspase-1 (Fig. 61) as a second potential trigger of caspase-3 activation. Although caspase-1 has been be associated with inflammatory processes (e.g. Furlan et al. 1999), which may be related to increased proliferation of microglia, staurosporine-induced apoptosis of cultured rat hippocampal neurones was previously demonstrated to involve the activation of caspase- 1 as an upstream initiator of the apoptotic cascade (Krohn et al. 1998). In addition, we have shown that the extrinsic apoptotic pathway, mediated by the death receptors and responsible for activating caspase- 8 , which can activate other caspases or cross-talk with the intrinsic mitochondrial pathway through the cleavage of Bid (Putcha et al. 2002), is not activated during selective AMPA receptor stimulation in hippocampal neurones. The importance of apoptotic cell death upon AMPA receptor-mediated excitotoxicity was previously demonstrated by the observation that overexpression of Bcl-2 in cultured cortical neurones protected against apoptosis induced by AMPA receptor activation, but not against necrosis induced by hydrogen peroxide (Cheung et al. 2000). Furthermore, apoptotic nuclear features of cell death induced by activation of AMPA receptors were previously observed in cerebellar granule cells (Cebers et al. 1997) or in cortical neurones (Larm et al. 1997).

Activation of non-desensitizing AMPA receptors was also shown to predispose the hippocampal neurones to a moderate increase in mitochondrial superoxide, as deter-

Table 2 Formation of intracellular peroxides in hippocampal neurones exposed to AMPA, under non-desensitizing conditions

\begin{tabular}{lllll}
\hline & Control & Control $+\mathrm{H}_{2} \mathrm{O}_{2}$ & $\mathrm{~A} / \mathrm{C}$ & $\mathrm{A} / \mathrm{C}+\mathrm{H}_{2} \mathrm{O}_{2}$ \\
\hline DCF fluorescence & $1.044 \pm 0.010$ & $1.362 \pm 0.084^{*}$ & $1.031 \pm 0.008$ & $1.185 \pm 0.044^{*}$ \\
Rhodamine-123 fluorescence & $1.319 \pm 0.025$ & $3.760 \pm 0.141^{*}$ & $1.330 \pm 0.031$ & $3.717 \pm 0.269^{*}$ \\
\hline
\end{tabular}

Values are mean \pm SEM increase above the initial fluorescence values (three to five experiments). Hippocampal neurones were incubated with

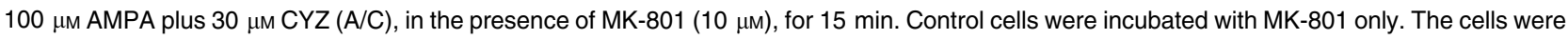
further incubated in Neurobasal medium for $24 \mathrm{~h}$, in the absence of the drugs. The formation of intracellular peroxides was determined with the fluorescent probes $\mathrm{DCFH}_{2}$-DA (DCF fluorescence) or DHR-123 (rhodamine-123 fluorescence). Where indicated, intracellular peroxide formation was determined after incubation with $10 \mathrm{mM} \mathrm{H}_{2} \mathrm{O}_{2}$, which was used to evaluate the oxidation status of the cells. ${ }^{*} p<0.001$ versus neurones incubated in the absence of $\mathrm{H}_{2} \mathrm{O}_{2}$ (one-way ANOVA followed by Tukey post-hoc test). 


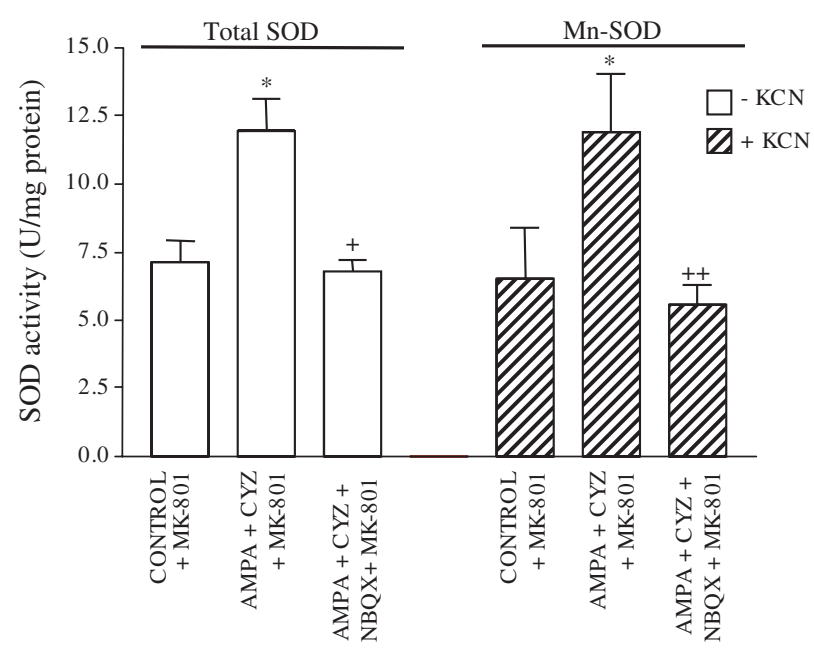

Fig. 8 SOD activity upon selective stimulation of AMPA receptors under non-desensitizing conditions. The neurones were incubated with $100 \mu \mathrm{m}$ AMPA in the presence of $30 \mu \mathrm{M} \mathrm{CYZ}+10 \mu \mathrm{M}$ MK-801, in the absence or presence of NBQX $(20 \mu \mathrm{m})$. In order to distinguish $\mathrm{Mn}$-SOD from Cu/Zn-SOD, the samples were incubated with $\mathrm{KCN}$, an inhibitor of $\mathrm{Cu} / \mathrm{Zn}-\mathrm{SOD}$. Values are mean $\pm \mathrm{SEM}$ of three to four experiments. ${ }^{*} p<0.05$ versus respective control; $+p<0.05$, $++p<0.01$ versus AMPA $+\mathrm{CYZ}+\mathrm{MK}-801$-treated cells (one-way ANOVA followed by Tukey post-hoc test).

mined with hydroethidine, which is oxidized to ethidium, redistributing across the mitochondrial membrane according to the transmembrane potential (Rottenberg 1984). In this study, the increase in ethidium fluorescence in a population of hippocampal neurones was observed only after addition of AA, similar to data obtained in single cerebellar granule cells (Budd et al. 1997), whereas further addition of carbonyl cyanide 4-trifluoro methoxy-phenylhydrazone (FCCP), a mitochondrial uncoupler, did not change significantly the overall ethidium fluorescence (not shown). Production of superoxide has been associated with increased NMDA or kainate excitotoxicity, namely through the inactivation of aconitase, a key enzyme in the citric acid cycle, which can lead to the disruption of mitochondrial energy production and cell death (Patel et al. 1996). Moreover, activation of AMPA receptors was previously shown to enhance the production of mitochondrial superoxide anions (Bindokas et al. 1996; Carriedo et al. 2000; A.C. Rego and D.G. Nicholls, unpublished results). A small molecule such as superoxide, generated by the xanthine-xanthine oxidase system, has also been associated with the potentiation of synaptic transmission in the CA1 area of the hippocampus, requiring the activation of protein kinase C (Knapp and Klann 2002), a process that may be envisaged as a natural role for superoxide. Furthermore, an enhancement in superoxide formation may also form the basis for cytochrome $c$ release and subsequent hippocampal neurodegeneration induced by AMPA plus CYZ, as reported by Atlante et al. (2000) in cerebellar granule neurones undergoing glutamate-induced excitotoxicity. Otherwise, superoxide generation may occur secondary to cytochrome $c$ release, as observed during NMDA neurotoxicity (Luetjens et al. 2000).

In this study, the increase in Mn-SOD activity can be regarded as a neuroprotective strategy to overcome mitochondrial superoxide production. Mn-SOD, localized predominantly in the neurones throughout the brain (Lindenau et al. 2000), was previously shown to mediate protection against NMDA- and nitric oxide-induced neurotoxicity (GonzalezZulueta et al. 1998). Overexpression of Mn-SOD was also shown to attenuate neuronal death in a model of amyotrophic lateral sclerosis, a progressive neurodegenerative disease associated with a mutation in the gene encoding the cytosolic $\mathrm{Cu} / \mathrm{Zn}-\mathrm{SOD}$ (SOD1) (Flanagan et al. 2002). Moreover, an increased expression of $\mathrm{Cu} / \mathrm{Zn}$ - SOD was shown to reduce oxidative stress and attenuate apoptotic cell death by decreasing mitochondrial cytochrome $c$ and second mitochondrial activation of caspases (Smac) release, and the activation of caspases (Sugawara et al. 2002), in agreement with previous studies that showed that SOD delayed neuronal apoptosis induced by nerve growth factor deprivation (Greenlund et al. 1995). Although increased generation of $\mathrm{H}_{2} \mathrm{O}_{2}$ by Mn-SOD might result in oxidative stress and neurotoxicity produced by the highly reactive hydroxyl radical, through the Fenton reaction, no changes in intracellular peroxide were observed, suggesting that severe oxidative stress may not determine AMPA-mediated neuronal injury. In accordance with this, we have observed that treatment of hippocampal neurones with the antioxidants vitamin $\mathrm{E}$ or idebenone did not prevent AMPA/CYZ-mediated cell death (data not shown).

In summary, the present study may help us to understand the susceptibility of hippocampal neurones to excitotoxicity mediated by AMPA receptor stimulation, by defining the downstream pathways of cell death occurring during neurodegeneration caused by epileptic seizures, ischaemia or Alzheimer's disease.

\section{Acknowledgements}

This work was supported by the Portuguese Foundation for Science and Technology, FCT, Project POCTI/1999/NSE/35875. We thank Dr Sancha Santos (Department of Zoology, Faculty of Science and Technology, University of Coimbra, Portugal) and Dr Cláudia Pereira (Institute of Biochemistry, Faculty of Medicine, University of Coimbra, Portugal), for assistance in the measurement of ATP/ ADP levels and the activity of SOD respectively.

\section{References}

Ambrósio A. F., Silva A. P., Malva J. O., Mesquita J. F., Carvalho A. P. and Carvalho C. M. (2000) Role of desensitization of AMPA receptors on the neuronal viability and on the $\left[\mathrm{Ca}^{2+}\right]_{\mathrm{i}}$ changes in cultured rat hippocampal neurons. Eur. J. Neurosci. 12, 2021-2031. 
Atlante A., Calissano P., Bobba A., Azzariti A., Marra E. and Passarella S. (2000) Cytochrome $c$ is released from mitochondria in a reactive oxygen species (ROS)-dependent fashion and can operate as a ROS scavenger and as a respiratory substrate in cerebellar neurons undergoing excitotoxic death. J. Biol. Chem. 275, 37159-37166.

Barria A. and Malinow R. (2002) Subunit-specific NMDA receptor trafficking to synapses. Neuron 35, 345-353.

Bennett M. V., Pellegrini-Giampietro D. E., Gorter J. A., Aronica E., Connor J. A. and Zukin R. S. (1996) The GluR2 hypothesis: $\mathrm{Ca}^{++}-$ permeable AMPA receptors in delayed neurodegeneration. Cold Spring Harb. Symp. Quant. Biol. 61, 373-384.

Bergmeyer H. U. and Bernt E. (1974) UV-assay with pyruvate and NADH, in Methods of Enzymatic Analysis (Bergmeyer H. U., ed.), pp. 574-579. Academic Press, New York.

Bindokas V. P., Jordán J., Lee C. C. and Miller R. J. (1996) Superoxide production in rat hippocampal neurons: selective imaging with hydroethidine. J. Neurosci. 16, 1324-1336.

Bradford M. M. (1976) A rapid and sensitive method for the quantification of microgram quantities of protein utilizing the principal of protein-dye-binding. Anal. Biochem. 72, 248-254.

Brorson J. R., Zhang Z. and Vandenberghe W. (1999) $\mathrm{Ca}^{2+}$ permeation of AMPA receptors in cerebellar neurons expressing Glu receptor 2. J. Neurosci. 19, 9149-9159.

Budd S. L., Castilho R. F. and Nicholls D. G. (1997) Mitochondrial membrane potential and hydroethidine-monitored superoxide generation in cultured cerebellar granule cells. FEBS Lett. 415, 2124.

Campagne M. L., Lucassen P. J., Vermeulen J. P. and Balázs R. (1995) NMDA and kainate induce internucleosomal DNA cleavage associated with both apoptotic and necrotic cell death in the neonatal rat brain. Eur. J. Neurosci. 7, 1627-1640.

Carriedo S. G., Yin H. Z., Sensi S. L. and Weiss J. H. (1998) Rapid $\mathrm{Ca}^{2+}$ entry through $\mathrm{Ca}^{2+}$-permeable AMPA/kainate channels triggers marked intracellular $\mathrm{Ca}^{2+}$ rises and consequent oxygen radical production. J. Neurosci. 18, 7727-7738.

Carriedo S. G., Sensi S. L., Yin H. Z. and Weiss J. H. (2000) AMPA exposures induce mitochondrial $\mathrm{Ca}^{2+}$ overload and ROS generation in spinal motor neurons in vitro. J. Neurosci. 20, 240-250.

Cebers G. and Liljequist S. (1995) Modulation of AMPA/kainate receptors by cyclothiazide increases cytoplasmic free $\mathrm{Ca}^{2+}$ and ${ }^{45} \mathrm{Ca}^{2+}$ uptake in brain neurons. Eur. J. Pharmacol. 290, 105-115.

Cebers G., Zhivotovsky B., Ankarcrona M. and Liljequist S. (1997) AMPA neurotoxicity in cultured cerebellar granule neurons: mode of cell death. Brain Res. Bull. 43, 393-403.

Cheung N. S., Beart P. M., Pascoe C. J., John C. A. and Bernard O. (2000) Human Bcl-2 protects against AMPA receptor-mediated apoptosis. J. Neurochem. 74, 1613-1620.

Flanagan S. W., Anderson R. D., Ross M. A. and Oberley L. W. (2002) Overexpression of manganese superoxide dismutase attenuates neuronal death in human cells expressing mutant (G37R) $\mathrm{Cu} / \mathrm{Zn}$ superoxide dismutase. J. Neurochem. 81, 170-177.

Furlan R., Martino G., Galbiati F., Poliani P. L., Smiroldo S., Bergami A., Desina G., Comi G., Flavell R., Su M. S. and Adorini L. (1999) Caspase-1 regulates the inflammatory process leading to autoimmune demyelination. J. Immunol. 163, 2403-2409.

Geiger J. R., Melcher T., Koh D. S., Sakmann B., Seeburg P. H., Jonas P. and Monyer H. (1995) Relative abundance of subunit mRNAs determines gating and $\mathrm{Ca}^{2+}$ permeability of AMPA receptors in principal neurons and interneurons in rat CNS. Neuron 15, 193-204.

Gonzalez-Zulueta M., Ensz L. M., Mukhina G., Lebovitz R. M., Zwacka R. M., Engelhardt J. F., Oberley L. W., Dawson V. L. and Dawson T. M. (1998) Manganese superoxide dismutase protects nNOS neurons from NMDA and nitric oxide-mediated neurotoxicity. J. Neurosci. 18, 2040-2055.
Gorter J. A., Petrozzino J. J., Aronica E. M., Rosenbaum D. M., Opitz T., Bennett M. V., Connor J. A. and Zukin R. S. (1997) Global ischemia induces down regulation of GluR2 mRNA and increases AMPA receptor-mediated $\mathrm{Ca}^{2+}$ influx in hippocampal CA1 neurons of gerbil. J. Neurosci. 17, 6179-6188.

Greenlund L. J., Deckwerth T. L. and Johnson E. M. Jr (1995) Superoxide dismutase delays neuronal apoptosis: a role for reactive oxygen species in programmed neuronal death. Neuron 14, 303315.

Itoh T., Itoh A., Horiuchi K. and Pleasure D. (1998) AMPA receptormediated excitotoxicity in human NT2-N neurons results from loss of intracellular $\mathrm{Ca}^{2+}$ homeostasis following marked elevation of intracellular $\mathrm{Na}^{+}$. J. Neurochem. 71, 112-124.

John C. A., Beart P. M., Giardina S. F., Pascoe C. J. and Cheung N. S. (1999) Cyclothiazide and GYKI 52466 modulate AMPA receptormediated apoptosis in cortical neuronal cultures. Neurosci. Lett. 268, 9-12.

Kiedrowski L. (1998) The difference between mechanisms of kainate and glutamate excitotoxicity in vitro: osmotic lesion versus mitochondrial depolarization. Res. Neurol. Neurosci. 12, 71-79.

Knapp L. T. and Klann E. (2002) Potentiation of hippocampal synaptic transmission by superoxide requires the oxidative activation of protein kinase C. J. Neurosci. 22, 674-683.

Krohn A. J., Preis E. and Prehn J. H. (1998) Staurosporine-induced apoptosis of cultured rat hippocampal neurons involves caspase1-like proteases as upstream initiators and increased production of superoxide as a main downstream effector. J. Neurosci. 18, 8186-8197.

Krohn A. J., Wahlbrink T. and Prehn J. H. M. (1999) Mitochondrial depolarization is not required for neuronal apoptosis. J. Neurosci. 19, 7394-7404.

Larm J. A., Cheung N. S. and Beart P. M. (1997) Apoptosis induced via AMPA-selective glutamate receptors in cultured murine cortical neurons. J. Neurochem. 69, 617-622.

Lechardeur D., Drzymala L., Sharma M., Zylka D., Kinach R., Pacia J., Hicks C., Usmani N., Rommens J. M. and Lukacs G. L. (2000) Determinants of the nuclear localization of the heterodimeric DNA fragmentation factor (ICAD/CAD). J. Cell Biol. 150, 321-334.

Lindenau J., Noack H., Possel H., Asayama K. and Wolf G. (2000) Cellular distribution of superoxide dismutases in the rat CNS. Glia 29, 25-34.

Lu Y. M., Yin H. Z., Chiang J. and Weiss J. H. (1996) $\mathrm{Ca}^{2+}$-permeable AMPA/kainate and NMDA channels: high rate of $\mathrm{Ca}^{2+}$ influx underlies potent induction of injury. J. Neurosci. 16, 5457-5465.

Luetjens C. M., Bui N. T., Sengpiel B., Münstermann G., Poppe M., Krohn A. J., Bauerbach E., Krieglstein J. and Prehn J. H. M. (2000) Delayed mitochondrial dysfunction in excitotoxic neuron death: cytochrome $c$ release and a secondary increase in superoxide production. J. Neurosci. 20, 5715-5723.

Malva J. O., Vieira A. P., Ambrósio A. F. and Oliveira C. R. (2003) Cobalt staining of hippocampal neurons mediated by non-desensitizing activation of AMPA but not kainate receptors. Neuroreport 14, 847-850

Matsuda K., Kamiya Y., Matsuda S. and Yuzaki M. (2002) Cloning and characterization of a novel NMDA receptor subunit NR3, a dominant subunit that reduces calcium permeability. Brain Res. Mol. Brain Res. 100, 43-52.

May P. C. and Robinson P. M. (1993) Cyclothiazide treatment unmasks AMPA excitotoxicity in rat hippocampal cultures. J. Neurochem. 60, 1171-1174.

Monteiro N. M., Rego A. C., Silva A. P., Malva J. O. and Oliveira C. R. (2001) Involvement of apoptosis and oxidative stress upon stimulation of non-desensitizing AMPA receptors in cultured hippocampal neurons. Eur. J. Biochem. 268, PS4-107. 
Mosmann T. (1983) Rapid colorimetric assay for cellular growth and survival: application to proliferation and cytotoxicity assays. J. Immunol. Meth. 65, 55-63.

Ohno K., Okada M., Tsutsumi R., Matsumoto N. and Yamaguchi T. (1998) Characterization of cyclothiazide-enhanced kainate excitotoxicity in rat hippocampal cultures. Neurochem. Int. 32, 265-271.

Opitz T., Grooms S. Y., Bennett M. V. L. and Zukin S. (2000) Remodeling of $\alpha$-amino-3-hydroxy-5-methyl-4-isoxazole-propionic acid receptor subunit composition in hippocampal neurons after global ischemia. Proc. Natl Acad. Sci. USA 97, 13360-13365.

Partin K. M., Patneau D. K., Winters C. A., Mayer M. L. and Buonanno A. (1993) Selective modulation of desensitisation of AMPA versus kainate receptors by cyclothiazide and concanavalin A. Neuron 11, 1069-1082.

Patel M., Day B. J., Crapo J. D., Fridovich I. and McNamara J. O. (1996) Requirement for superoxide in excitotoxic cell death. Neuron 16, 345-355.

Pellegrini-Giampietro D. E., Gorter J. A., Bennett M. V. L. and Zukin R. S. (1997) The GluR2 (GluR-B) hypothesis: $\mathrm{Ca}^{2+}$-permeable AMPA receptors in neurological disorders. Trends Neurosci. 20, 464-470.

Pickard L., Noel J., Henley J. M., Collingridge G. L. and Molnar E. (2000) Developmental changes in synaptic AMPA and NMDA receptor distribution and AMPA receptor subunit composition in living hippocampal neurons. J. Neurosci. 20, 7922-7931.

Putcha G. V., Harris C. A., Moulder K. L., Easton R. M., Thompson C. B. and Johnson E. M. Jr (2002) Intrinsic and extrinsic pathway signaling during neuronal apoptosis: lessons from the analysis of mutant mice. J. Cell Biol. 157, 441-453.

Rego A. C., Santos M. S. and Oliveira C. R. (1999) Influence of the antioxidants vitamin $\mathrm{E}$ and idebenone on retinal cell injury mediated by chemical ischemia, hypoglycemia, or oxidative stress. Free Radic. Biol. Med. 26, 1405-1417.
Rego A. C., Ward M. W. and Nicholls D. G. (2001) Mitochondria control AMPA/kainate receptor-induced cytoplasmic calcium deregulation in rat cerebellar granule cells. J. Neurosci. 21, 1893-1901.

Rottenberg H. (1984) Membrane potential and surface potential in mitochondria: uptake and binding of lipophilic cations. J. Memb. Biol. 81, 127-138.

Royall J. A. and Ischiropoulos H. (1993) Evaluation of 2',7'-dichlorofluorescin and dihydrorhodamine 123 as fluorescent probes for intracellular $\mathrm{H}_{2} \mathrm{O}_{2}$ in cultured endothelial cells. Arch. Biochem. Biophys. 302, 348-355.

Silva A. P., Malva J. O., Ambrósio A. F., Salgado A. J., Carvalho A. P. and Carvalho C. M. (2001) Role of kainate receptor activation and desensitization on the $\left[\mathrm{Ca}^{2+}\right]_{\mathrm{i}}$ changes in cultured rat hippocampal neurons. J. Neurosci. Res. 65, 378-386.

Simonian N. A., Getz R. L., Leveque J. C., Konradi C. and Coyle J. T. (1996) Kainate induces apoptosis in neurons. Neuroscience 74, 675-683.

Sugawara T., Noshita N., Lewén A., Gasche Y., Ferrand-Drake M., Fujimura M., Morita-Fujimura Y. and Chan P. H. (2002) Overexpression of copper/zinc superoxide dismutase in transgenic rats protects vulnerable neurons against ischemic damage by blocking the mitochondrial pathway of caspase activation. J. Neurosci. 22, 209-217.

Tanaka H., Grooms S. Y., Bennett M. V. L. and Zukin R. S. (2000) The AMPAR subunit GluR2: still front and center-stage. Brain Res. 886, 190-207.

Troy C. M. and Shelanski M. L. (1994) Down-regulation of copper/zinc superoxide dismutase causes apoptotic death in PC12 neuronal cells. Proc. Natl Acad. Sci. USA 91, 6384-6387.

Troy C. M., Rabacchi S. A., Friedman W. J., Frappier T. F., Brown K. and Shelanski M. L. (2000) Caspase-2 mediates neuronal cell death induced by $\beta$-amyloid. J. Neurosci. 20, 1386-1392. 